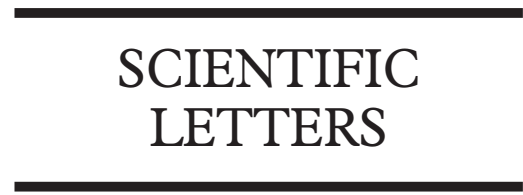

Decreased adrenomedullin production in the coronary circulation of patients with coronary artery disease

Adrenomedullin is a novel peptide first isolated from human pheochromocytoma and later proved to be secreted from the adrenal medulla, heart, vascular smooth muscle cells, and endothelial cells. ${ }^{2}$ Adrenomedullin has not only vasoactive but also antimitogenic effects on the vascular tissue. ${ }^{3}$ However, endothelin-1 has been widely known to be a potent atherogenic factor. ${ }^{4}$ We investigated adrenomedullin and endothelin-1 production in the coronary circulation of patients with coronary artery disease.

We studied 18 patients with coronary artery disease (12 men and six women, mean age $61.2(10.0)$ years, range $36-83$ years) and seven control subjects without coronary artery lesions (six men and one women, mean age 60.0 (10.5) years, range $46-72$ years) who underwent diagnostic coronary angiography. All subjects gave their informed consent to participate in the study. Subjects with heart failure, renal failure, hepatic failure or contraindication for cardiac catheterisation were excluded. Blood samples were drawn from the ascending aorta and coronary sinus via heparin coated catheters. Plasma adrenomedullin and endothelin-1 concentrations were measured by radioimmunoassay as described previously. ${ }^{56}$

In the control subjects, plasma adrenomedullin concentrations in the coronary sinus were significantly higher than those in the aorta (fig 1A), suggesting that adrenomedullin is produced in the coronary circulation. In contrast, in patients with coronary artery disease, adrenomedullin concentrations in the coronary sinus did not differ from those in the aorta. Adrenomedullin concentrations in the coronary sinus, not in the aorta, were significantly higher in the control subjects than in the patients. The difference in adrenomedullin concentrations between the coronary sinus and aorta, which reflects adrenomedullin production in coronary circulation, was significantly lower in the patients $(0.7(0.3) \mathrm{fmol} / \mathrm{ml})$ than in the control subjects $(3.2(0.9) \mathrm{fmol} / \mathrm{ml})$. On the other hand, plasma endothelin-1 concentrations in the aorta and coronary sinus did not differ between patients with coronary artery disease and the control subjects (fig 1B).

Intravenous administration of adrenomedullin elicits a potent and long lasting vasodilating effect in vivo. Adrenomedullin also inhibits proliferation of vascular smooth muscle cells in vitro. ${ }^{3}$ Kohno and colleagues found that adrenomedullin inhibits endothelin-1 synthesis in vascular smooth muscle cells. We reported that adrenomedullin stimulates nitric oxide production by vascular smooth muscle cells. ${ }^{8}$ These observations support the premise that adrenomedullin could act as a potent antiatherogenic factor in vivo. Although the precise kinetics of adrenomedullin in the coronary circulation are still unclear, the present study suggests that decreased adrenomedullin production in the coronary circulation may be related to the formation

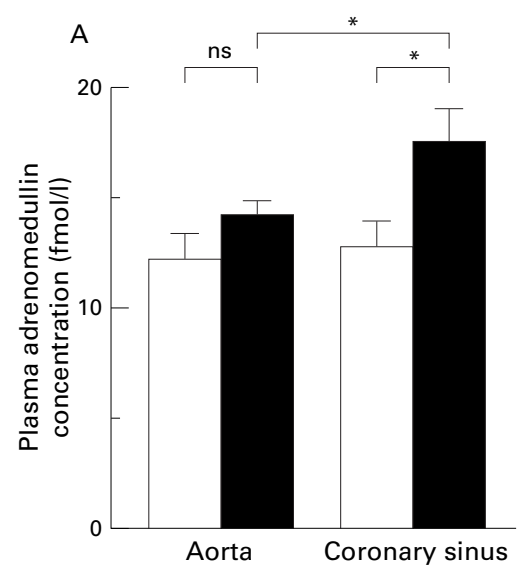

Commentary

Adrenomedullin is a circulating vasodilator peptide expressed in a number of cell types with several potentially important antiproliferative actions on vascular cells. It inhibits angiotensin II stimulated smooth muscle cell migration, stimulates nitric oxide release from smooth muscle cells, and inhibits endothelin release from endothelial cells. The present report shows that basal production of adrenomedullin in the human coronary circulation is attenuated in subjects with coronary atherosclerosis. This observation could be relevant for extending our understanding of this peptide's regulatory role in the development of coronary artery disease.

G F BAXTER Associate Editor

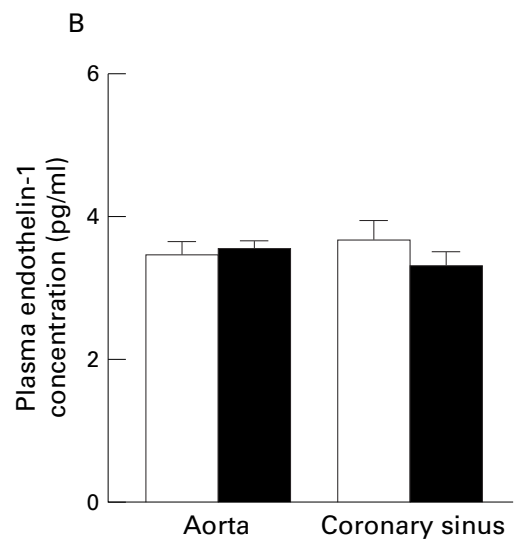

Figure 1 Plasma adrenomedullin $(A)$ and endothelin-1 (B) concentrations in the aorta and coronary simus in patients with coronary artery disease (white columns) and control subjects (black columns). Comparisons between the two groups were analysed by unpaired or paired Student's $t$ test. Data are mean (SEM). ${ }^{\star} p<0.05 ; n s$, not significant.

and progression of coronary artery lesions in patients with coronary artery disease.

YUKIHIRO HOJO UICHI IKEDA TAKA-AKI KATSUKI KAZUYUKI SHIMADA

Department of Cardiology, fichi Medical School, Minamikawachi, Tochigi 329-0498, Japan email vikeda@jichi.ac.jp

1 Kitamura K, Kangawa K, Kawamoto M, et al. Isolation and characterization of peptides which act on rat platelets, from a pheochromocytoma. Biochem Biophys Res Commun 1992;185:134-41.

2 Kitamura $\mathrm{K}$, Kangawa $\mathrm{K}$, Matsuo $\mathrm{H}$, et al. Adrenomedullin: implication for hypertension research. Drugs 1995;49:485-95.

3 Kano H, Kohno M, Yasunari K, et al. Adrenomedullin as a novel antiproliferative factor of vascular smooth muscle cells. F Hypertens 1996;14:

4 Alberts GF, Peifley KA, Johns A, et al. Constitutive endothelin-1 overexpression promotes smooth muscle cell proliferation via an external autocrine loop. F Biol Chem 1994;269:1011218

5 Yamamoto K, Ikeda U, Mito H, et al. Endothelin production in pulmonary circulation of patients with mitral stenosis. Circulation 1994; 89:2093-8.

6 Yamamoto K, Ikeda U, Sekiguchi H, et al. Plasma levels of adrenomedullin in patients with mitral stenosis. Am Heart F 1998;135:542-9.

7 Kohno M, Kano H, Horio T, et al. Inhibition of endothelin producion by adrenomedullin in endothelin producion by adrenomedullin in vascular smooth muscle cells. Hypertension

8 Ikeda U, Kanbe T, Shimada K. Adrenomedullin increases inducible nitric oxide synthase in rat increases inducible nitric oxide synthase in rat
vascular smooth muscle cells stimulated with vascular smooth muscle cells stimulated with
interleukin-1. Hypertension 1996;27:1240-4.

\section{WEB TOP 10}

www.heartjnl.com

These articles scored the most hits on Heart's web site during April 2000

1 Joint British recommendations on prevention of coronary heart disease in clinical practice

December 1998;80(suppl 2):S1-29

2 Epidemiology, aetiology, and prognosis of heart failure

J J McMurray, S Stewart

May 2000;83:596-602 (Education in Heart)

3 The cardiomyopathies: an overview M J Davies

April 2000;83:469-74 (Education in Heart)

4 Troponin $T$ or troponin I as cardiac markers in ischaemic heart disease S J Maynard, I B A Menown, A A J Adgey

April 2000;83:371-3 (Editorial)

5 Intervention in coronary artery disease

$\mathrm{S}$ Windecker, B Meier

April 2000;83:481-90 (Education in Heart)

6 Coronary angioplasty is like going to the dentist

B Meier

May 2000;83:491-2 (Editorial)

7 Arrhythmogenic right ventricular cardiomyopathy: diagnosis, prognosis, and treatment

D Corrado, C Basso, G Thiene

May 2000;83:588-95 (Education in Heart)

8 Left ventricular free wall rupture: clinical presentation and management

J Figueras, J Cortadellas, J Soler-Soler May 2000;83:499-504 (Review)

9 Cardiovascular risks and outcomes: ethnic variations in hypertensive patients

R Bhopal, S Sengupta-Wiebe May 2000;83:495-6 (Editorial)

10 The aortic root: structure, function, and surgical reconstruction M J Underwood, G El Khoury, D Deronck, D Glineur, R Dion Apr 2000;83:376-80 (Review) 